\title{
Geospatial Compilation of Results from Field Sample Collection in Support of Mineral Resource Investigations, Western Alaska Range, Alaska, July 2013
}

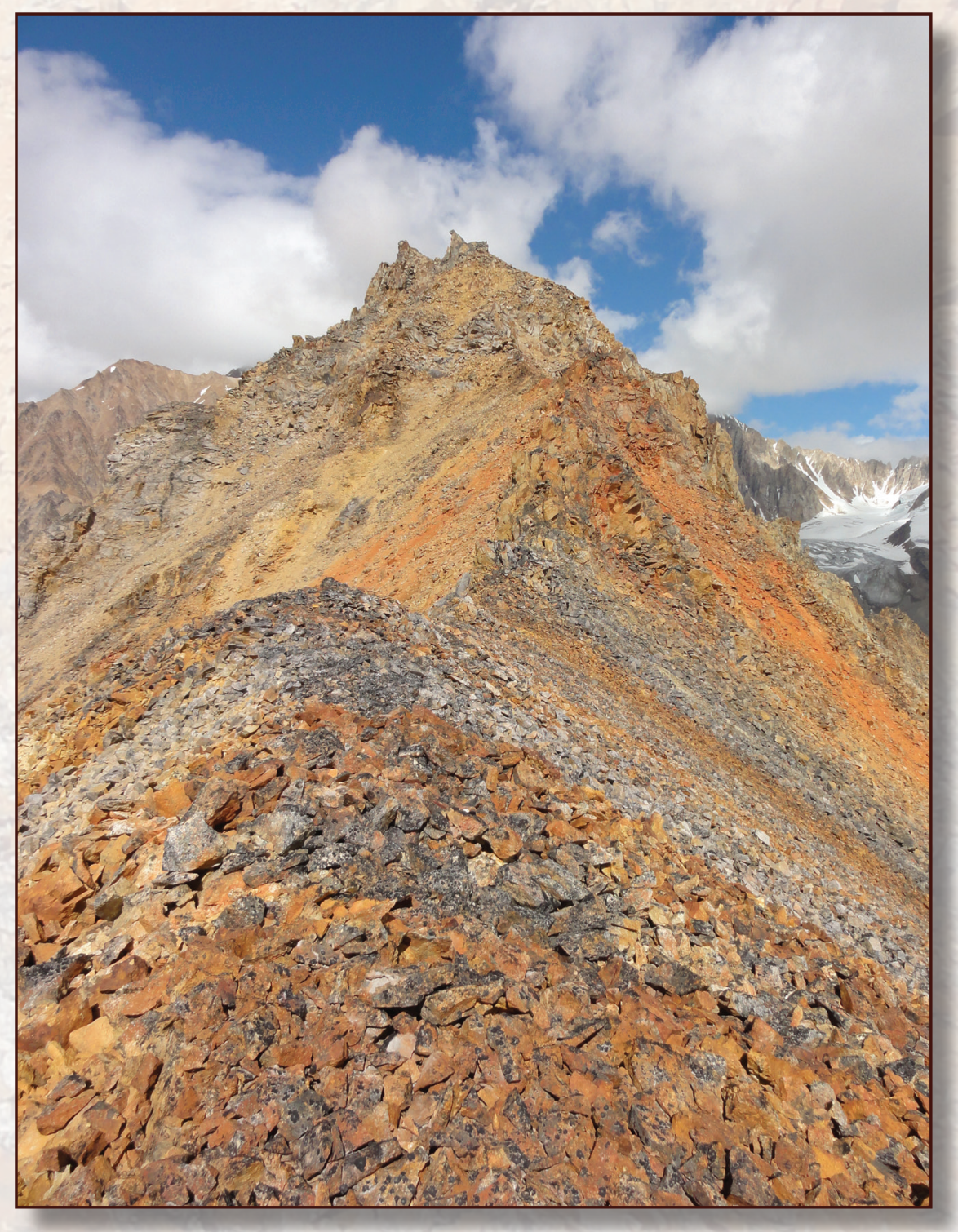

Data Series 943 
Cover. Photograph showing strong color anomaly from site 8 approximately 30 kilometers southeast of Mount Estelle in the western Alaska Range, Alaska. Photograph by: Michaela Johnson, July 16, 2013. 


\section{Geospatial Compilation of Results from Field Sample Collection in Support of Mineral Resource Investigations, Western Alaska Range, Alaska, July 2013}

By Michaela R. Johnson, Garth E. Graham, Bernard E. Hubbard, and William M. Benzel

Data Series 943 


\title{
U.S. Department of the Interior SALLY JEWELL, Secretary
}

\section{U.S. Geological Survey \\ Suzette M. Kimball, Acting Director}

\author{
U.S. Geological Survey, Reston, Virginia: 2015
}

For more information on the USGS - the Federal source for science about the Earth, its natural and living resources, natural hazards, and the environment—visit http://www.usgs.gov or call 1-888-ASK-USGS.

For an overview of USGS information products, including maps, imagery, and publications, visit http://www.usgs.gov/pubprod/.

Any use of trade, firm, or product names is for descriptive purposes only and does not imply endorsement by the U.S. Government.

Although this information product, for the most part, is in the public domain, it also may contain copyrighted materials as noted in the text. Permission to reproduce copyrighted items must be secured from the copyright owner.

Suggested citation:

Johnson, M.R., Graham, G.E., Hubbard, B.E., and Benzel, W.M., 2015, Geospatial compilation of results from field sample collection in support of mineral resource investigations, Western Alaska Range, Alaska, July 2013: U.S. Geological Survey Data Series 943, 12 p., http://dx.doi.org/10.3133/ds943.

ISSN 2327-638X (online) 


\section{Contents}

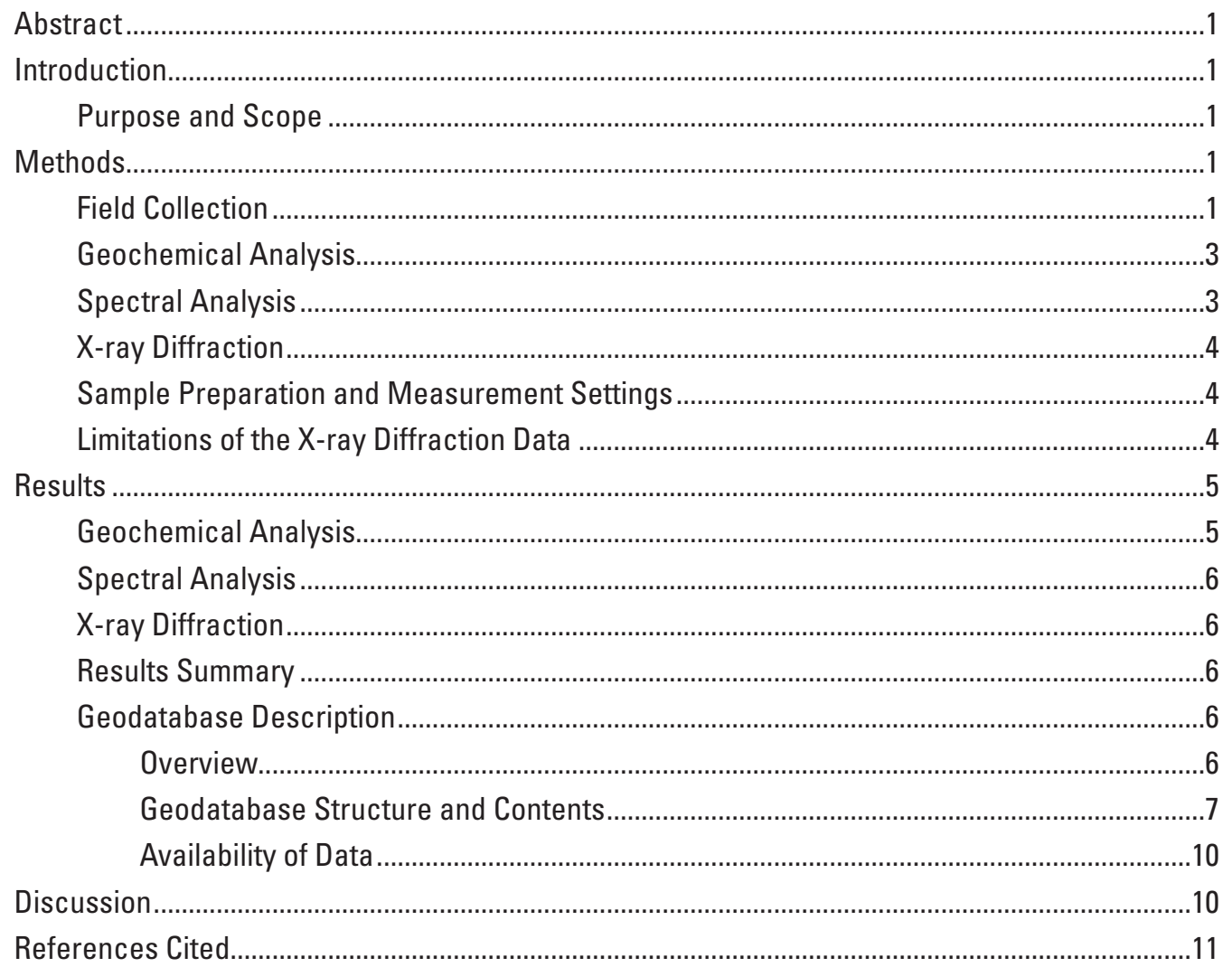

\section{Figures}

1. Map showing locations of areas visited near Mount Estelle, Alaska, in July 2013...........2

2. Photograph showing strong color anomaly from site 8 approximately 30 kilometers southeast of Mount Estelle in the western Alaska Range, Alaska.....................................6

3. Graphic showing location of analyses results tables within the geodatabase

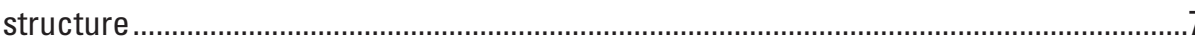

4. Illustration of geodatabase relationships between feature classes within the feature dataset, location, and the analyses results for spectral measurements and grab samples collected July 2013 in the western Alaska Range.

5. Graphic showing the capability of accessing related table information from

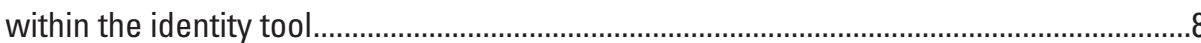

6. Graphic showing the capability of accessing related tables from within an attribute tables using the button, "Related Tables".

7. Example of geodatabase display showing the site location and information with the associated photos within the ArcGIS environment

8. Graphic showing location of the HTML popup button; right of hyperlink button (lightning bolt) and left of measurement button (ruler) .

9. Configuration of HTML Popup tool for shapefile version of the dataset..........................10 


\section{Tables}

1. Minerals by alteration type that can be identified using hyperspectral techniques ........3

2. Gold concentration, spectral characterization, and X-ray diffraction results for samples analyzed from Island Mountain and site 8 in the western Alaska Range ...........5

\section{Conversion Factors}

SI to Inch/Pound

\begin{tabular}{|c|c|c|}
\hline Multiply & By & To obtain \\
\hline & Length & \\
\hline meter (m) & 3.281 & foot (ft) \\
\hline kilometer $(\mathrm{km})$ & 0.6214 & mile (mi) \\
\hline
\end{tabular}

Horizontal coordinate information is referenced to the World Geodetic System of 1984, WGS 1984. 


\title{
Geospatial Compilation of Results from Field Sample Collection in Support of Mineral Resource Investigations, Western Alaska Range, Alaska, July 2013
}

\author{
By Michaela R. Johnson, Garth E. Graham, Bernard E. Hubbard, and William M. Benzel
}

\section{Abstract}

This Data Series summarizes results from July 2013 sampling in the western Alaska Range near Mount Estelle, Alaska. The fieldwork combined in situ and camp-based spectral measurements of talus/soil and rock samples. Five rock and 48 soil samples were submitted for quantitative geochemical analysis (for 55 major and trace elements), and the 48 soils samples were also analyzed by x-ray diffraction to establish mineralogy and geochemistry. The results and sample photographs are presented in a geodatabase that accompanies this report. The spectral, mineralogical, and geochemical characterization of these samples and the sites that they represent can be used to validate existing remote-sensing datasets (for example, ASTER) and future hyperspectral studies. Empirical evidence of jarosite (as identified by x-ray diffraction and spectral analysis) corresponding with gold concentrations in excess of 50 parts per billion in soil samples suggests that surficial mapping of jarosite in regional surveys may be useful for targeting areas of prospective gold occurrences in this sampling area.

\section{Introduction}

The U.S. Geological Survey (USGS) is conducting pilot studies investigating the applicability of space-borne and airborne remote sensing technology to mapping of geologic and land-cover materials in Alaska. As part of this effort, groundbased work (including spectroscopy as well as sediment and rock sampling) was conducted in July 2013 in the western Alaska Range. Direct sampling and field-based spectroscopy permitted characterization of surficial and bedrock materials. The results presented in this Data Series were collected in preparation for future imaging spectroscopy collections and will be used for validation of the remote sensing data. These results can also be used to validate existing data such as Advanced Spaceborne Thermal Emission and Reflection Radiometer (ASTER) (Hubbard and others, 2007).

\section{Purpose and Scope}

The purpose of this Data Series is to compile, organize, and archive field locations and sample photos collected in July 2013 with geochemical, mineraological, and spectral analytical results. The information is organized for use in a geodatabase containing the site locations, results, and sample photographs (Esri, 2014).

\section{Methods}

\section{Field Collection}

From July 14-20, 2013, USGS personnel conducted helicopter-supported site visits to 18 areas in the western Alaska Range approximately 180 kilometers $(\mathrm{km})$ (110 miles [mi]) northwest of Anchorage (fig. 1). The sites included known gold $\mathrm{Au}$ ) and base-metal prospects as well as green-fields areas where anomalous color or localized recessive weathering suggested hydrothermal alteration within latest Cretaceous to early Tertiary granitic intrusions. The objectives of the reconnaissance visits in areas were to collect: (1) representative geologic samples (rocks, talus fines [referred to herein as "soils"]) for spectral characterization of these sites and (2) in-situ ground-based hyperspectral data along geologic traverses when weather permitted.

Representative grab samples of rocks and soils were placed in sample bags and labeled, and coordinates and field data for samples were recorded. Spectral measurements of in situ geologic materials were made using an Analytical Spectral Devices (ASD) field spectrometer. During the first two days (July 14-15, 2013), conditions allowed for field measurements. Skies were sunny or partly sunny, so sunlight was the source of illumination. On these days, integrated reflectance measurements, each covering several square meters, were recorded at points along traverses. Under cloudy skies, an ASD light probe attachment was used to provide artificial illumination. With a light probe attached, the ASD measurements are made over small, 1-square-centimeter spots. The reflectance spectra of rocks and soils were recorded at incremental steps along each traverse. Cloudy and commonly wet weather (which adversely affects spectral signatures) precluded further 


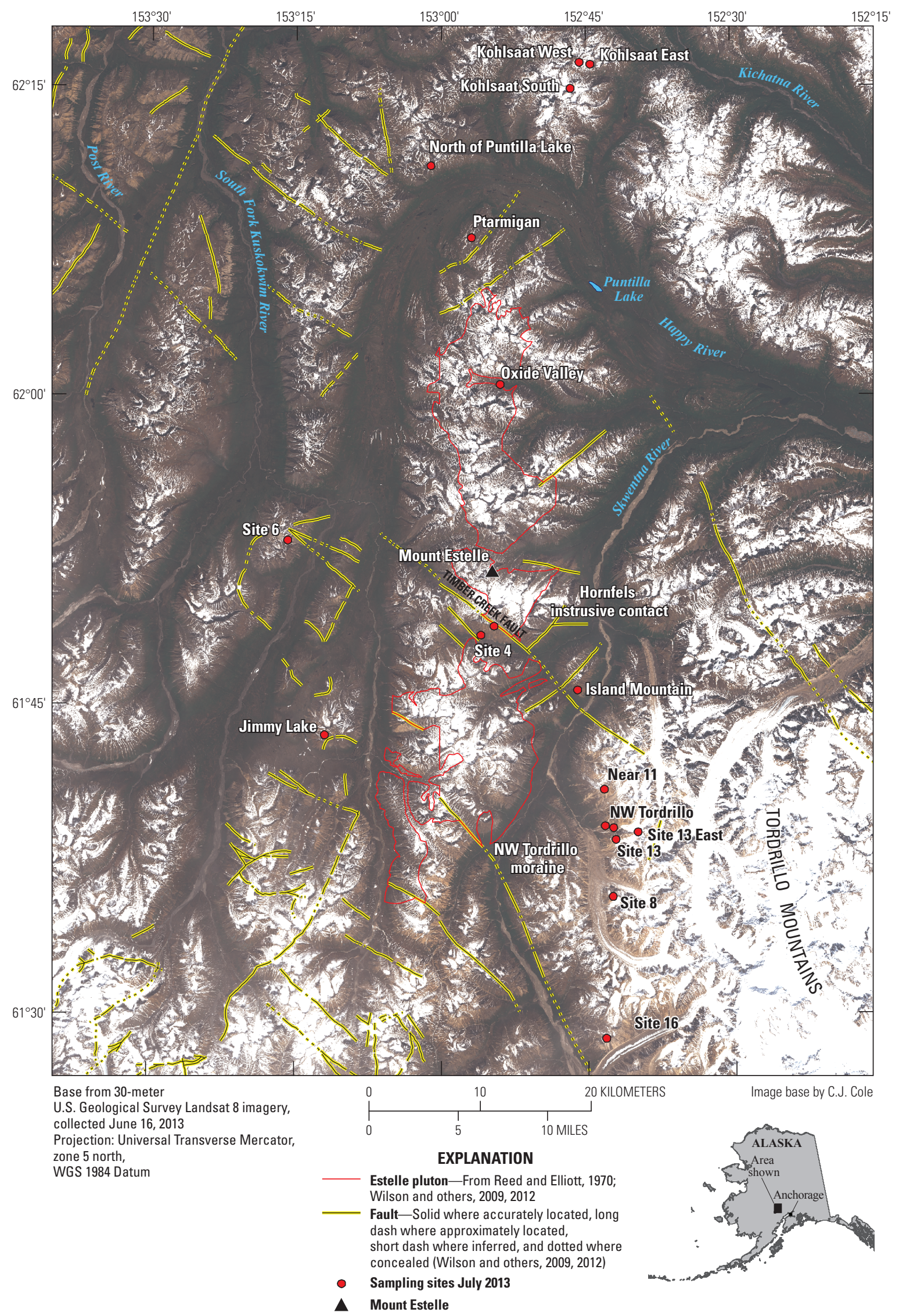

Figure 1. Locations of areas visited near Mount Estelle, Alaska, in July 2013. The background image is a color composite of Landsat 8 imagery (U.S. Geological Survey, 2014). 
spectral measurements of in situ materials. Instead, spectral measurements were made using the ASD light probe on the representative rock and soil samples brought back to camp.

The soils, along with five rock samples, were also analyzed to determine concentrations of select major and trace elements, and 48 of the soils were analyzed by X-ray diffraction (XRD) to establish mineralogy. The mineralogical data provided a verification for the spectral interpretations. Comparison of XRD and spectral data to trace element and gold concentrations provided insight into correlations between observed mineralogy and areas of high base or precious metal concentrations. Observed correlations between hyperspectral mineral classification and elevated metals could then be used to select other areas with similar spectral signatures as prospective for mineral occurrences.

\section{Geochemical Analysis}

Forty-eight soil samples and five rock samples were selected for geochemical analysis. The majority of analyses were conducted on soil samples for two reasons. First, as weathering products of the surrounding host rocks, soils reflect a larger source area for metals than individual rocks, which increases the probability of identifying anomalous metal concentrations. Second, many of the minerals that can be identified using hyperspectral techniques (including micas, clays, and sulfates) (Thompson and others, 2009) (table 1) are likely more highly concentrated in the fine sediment than in individual rock samples (for example, granites, graywackes). The five rock samples were selected because they contained veins or appeared to contain alteration minerals (micas and clays) that might be indicative of hydrothermal alteration and, thus, appeared to contain high metal concentrations.

Fifty-five major, rare earth, and trace elements were determined for each sample by inductively coupled plasmaatomic emission spectrometry (ICP-AES) and inductively coupled plasma-mass spectrometry (ICP-MS), and the presence of $\mathrm{Au}$ was determined by fire assay on a contract lab basis for the USGS by SGS Minerals Services in
Lakefield, Ontario, Canada. Descriptions and methods of analysis are described in SGS Mineral Services (2013) and at http://minerals.cr.usgs.gov/projects/analytical_chem/references. html. Sample preparation for major, rare earth, and trace elements involved decomposition of each sample using a sodium peroxide sinter at $450{ }^{\circ} \mathrm{C}$. The resultant cake was leached with water and acidified with nitric acid. The samples were then digested using tartaric acid. Aliquots of the digested sample were analyzed by ICP-AES and the ICP-MS to determine concentrations of select elements. Calibration on the ICP-AES was performed with digested rock reference materials and a series of multi-element solution standards. The ICP-MS was calibrated with aqueous standards, and internal standards were used to compensate for matrix affects and internal drifts.

\section{Spectral Analysis}

Field and laboratory spectral measurements were conducted using an Analytical Spectral Device (ASD) spectrometer measuring reflected radiation from 350-2,500 nanometers (nm) at approximately 1-nm spectral sampling. In situ field measurements and samples were collected both from known mineral occurrences near the Mount Estelle pluton (Reed and Elliott, 1970; Wilson and others, 2009; Wilson and others, 2012) (fig. 1) and from areas where recessed topography suggested intense destructive alteration of host rocks (sites within the Tordrillo Mountains) based on preliminary analysis of remote sensing imagery, supporting Alaska Resource Data Files (ARDF), and existing geologic maps (U.S. Geological Survey, 2012). Many of these measurements were collected along linear traverses with distances ranging from 9-140 meters in length, in order to provide ground truth information comparable to the spatial resolution of various hyperspectral and multispectral sensors such as HyMap ${ }^{\mathrm{TM}}$ (Hyperspectral Mapper) (Cocks and others, 1998) and Advanced Spaceborne Thermal Emission and Reflection Radiometer (ASTER; NASA-JPL, 2014). Some of these measurements may be useful for ground-to-pixel calibration of imagery acquired by future airborne hyperspectral surveys or spaceborne hyperspectral sensors.

Table 1. Minerals by alteration type that can be identified using hyperspectral techniques (Thompson and others, 2009).

\begin{tabular}{|c|c|c|}
\hline Alteration type & Mineral assemblages & Comments \\
\hline Argillic & $\begin{array}{l}\text { kaolinite, dickite, montmorillonite, illite/ } \\
\text { smectite, chlorite, calcite and epidote }\end{array}$ & $\begin{array}{l}\text { Mostly exposed well in porphyry (intrusive) mineral deposits (usually too } \\
\text { small to see or map in linear-dominated epithermal and polymetallic } \\
\text { vein systems) }\end{array}$ \\
\hline Greisen & topaz and tourmaline & Mostly in tin-bearing areas and the largest granitic and pegmatite exposures \\
\hline Ferric/laterite/bauxite & kaolinite, gibbsite, goethite, quartz & $\begin{array}{l}\text { Lumped class which includes strong goethite, mineral gossanized areas, } \\
\text { unusual ferricrete-indistinguishable deposits, and paleo-bauxite and } \\
\text { laterite deposits rich in aluminum }\end{array}$ \\
\hline
\end{tabular}


Four types of ASD measurements were conducted from July 14-21, 2013: (1) in situ linear field traverses using natural sunlight as the light source, (2) random "sub-pixel" or point location measurements of various rocks and rock coatings such as iron-staining and lichen cover, (3) in situ linear field traverse using an external probe attachment with its own artificial light source, and (4) base-camp- and laboratory-based measurement of collected rock and soil samples using the external light probe attachment. All reflectance measurements were made relative to Spectralon ${ }^{\circledR}$, a white high-reflectivity plastic standard with a known and nearly constant spectral response pattern. Measurement types 1 and 2 were conducted during two days of mostly sunny weather (July 14-15, 2013), while the remaining measurements were done during periods of mostly cloudy weather conditions (July 16-21, 2013). The spectra are stored in SPECPR (SPECtrum Processing Routines) file format (Clark, 1993).

Using PRISM (Kokaly, 2011), each individual traverse measurement and groups of similar point target measurements (measurement types 1 through 3 ) were averaged and corrected for minor absorptions inherent to the spectralon reference material, as well as spectral offsets between individual detectors of the ASD instrument. This procedure yielded measurements of absolute reflectance which are comparable to spectra of reference materials within spectral libraries (for example, USGS digital spectral library; Clark and others, 2007). Sample spectra measured in the lab and base camp (measurement type 4) were corrected for spectralon and ASD detector offsets, but were not averaged.

The resulting absolute reflectance spectral profiles were processed using the Material Identification and Characterization Algorithm (MICA; Kokaly, 2011), implemented as a subroutine within PRISM. The tool, MICA, builds on the legacy of the USGS Tetracorder algorithm (Clark and others, 2003) by identifying spectrally dominant materials based on comparison of observed reflectance spectra with a reference spectral library of minerals, vegetation, water, and other materials. Typically, two spectral analyses are generated using MICA for mineral characterization. The results of these analyses are used to produce material maps based on wavelength regions. The first analysis is for a set of minerals with absorption features in the visible and near-infrared wavelength region $(400-1,000 \mathrm{~nm}$, or 1 micron), which is used to produce maps of iron-bearing minerals (for example, King and others, 2011). The second analysis is for a set of minerals with absorption features in the shortwave infrared (1,000-2,500 nm, or 2 micron), which is used to produce maps of carbonates, phyllosilicates, sulfates, altered minerals, and other materials (for example, Kokaly and others, 2011). In this case, the latest version of the USGS spectral library (splib06a; Clark and others, 2007) was used in conjunction with the same MICA command file used in the construction of 1-micron and 2-micron mineral maps of Afghanistan (Kokaly and others, 2013), but modified to include 1-micron and 2-micron absorption features associated with the Fe-smectite mineral, nontronite. A more detailed description of this command file and a complete list of identifiable materials and spectral features are provided by Kokaly and others, 2013.

\section{X-ray Diffraction}

\section{Sample Preparation and Measurement Settings}

Five-gram splits of each sample were ground to pass 100 mesh sieve (150 microns), then side-packed into XRD sample mounts and scanned on the PANalytical X-ray diffractometer (PANalytical, 2014) using the following instrument conditions:

- PANalytical "X'Pert Pro - MPD X-ray Diffractometer

- Theta/Theta geometry

- Copper $(\mathrm{Cu})$ long-fine-focus X-ray tube (Nickel (Ni) filtered)

- "X'celerator" solid state "strip" detector

- 45 kilovolt, 40 milliamps

- 15 millimeter beam mask

- $1 / 2^{\circ}$ anti-scatter slit

- $1 / 4^{\circ}$ divergence slit

- $1 / 2^{\circ}$ receiving anti-scatter slit

- $1 / 4^{\circ}$ receiving divergence slit

- step size $0.033^{\circ}$ in continuous scan mode

- scan range of $5^{\circ}$ to $65^{\circ}$ two-theta

- sample spinner set to 'on'

- scan rate of $2^{\circ}$ per minute (total scan time of 30 minutes)

Identification of mineral phases was done with Material Data Inc. (MDI) Jade (v. 9.5) search-match software (Materials Data Inc., 2009) using the ICDD's "2009 PDF-4" (International Centre for Diffraction Data, 2010) and National Institute Standards and Technology "FIZ/NIST Inorganic ICSD" databases (Fachinformationszentrum Karlsruhe [FIZ] and the National Institute of Standards and Technology [NIST], 2014). Semi-quantitative mineral estimates were calculated using MDI Whole Pattern Fit software, which simultaneously calculates a whole pattern fit and a Rietveld refinement of the minerals. All data were normalized to 100 percent based on the identified minerals. A full description of the Whole Pattern Fit algorithm is available from MDI (Materials Data Inc., 2009).

\section{Limitations of the X-ray Diffraction Data}

X-ray diffraction analysis measures the crystalline portion of the sample. This does not include any amorphous phase that may be present nor any organic component. The typical detection limit by X-ray diffraction is between 1 and 3 percent by weight depending on the crystallinity of the phase and interference from overlapping lines from other phases. Thus, there may be trace phases present, but they may be neither identified nor included in the model. Typical errors for semiquantitative mineral values are: 
- Major phases (greater than 15 percent by weight): \pm 10 percent of the reported amount;

- Minor phases (5-15 percent by weight): \pm 20 percent of the reported amount; and

- Trace phases (less than 5 percent): \pm 100 percent of the amount reported.

Finally, clay mineral identifications from whole rock patterns are treated as nominal assignments until the clay mineralogy is confirmed by a clay analysis (Moore and Reynolds, 1997; Poppe and others, 2001).

\section{Results}

\section{Geochemical Analysis}

Fifteen (two samples with duplicates) of the 48 soil samples returned detectable $\mathrm{Au}$ concentrations (greater than 5 parts per billion [ppb]). Four samples, including one from Island Mountain (13hy001) and three from a strong color anomaly (Site 8 in the database; fig. 1) (13hy047, 13hy047-duplicate, 13hy055, and 13hy056) contained greater than $50 \mathrm{ppb}$ gold (table 2). The Island Mountain sample, 13hy001, was collected over known $\mathrm{Au}-\mathrm{Cu}$ mineralization hosted within an actinolite breccia. This sample yielded the highest $\mathrm{Au}(576 \mathrm{ppb})$ and copper $(\mathrm{Cu})(357 \mathrm{ppm})$ concentrations and arsenic (As) (390 parts per million [ppm]), bismuth (Bi) (2.6 ppm), sulfur (S) (0.74 weight percent), and antimony $(\mathrm{Sb})(18.2 \mathrm{ppm})$ concentrations above the 90th percentile (based on number of samples). The three samples from site 8 (13hy047, 13hy055, and 13hy056) contained between 79 and $181 \mathrm{ppb} \mathrm{Au}$, 90th percentile $\mathrm{S}$ ( 0.48 to 2 weight percent), upper quartile to 90 th percentile $\mathrm{Bi}$ (1.1 to $1.9 \mathrm{ppm}$ ), and background to upper quartile $\mathrm{Cu}$ (98 and $99 \mathrm{ppm}$ ) concentrations. Detectable Au was also measured in three additional samples (including one duplicate: 13hy060, 13hy061, and 13hy062) from site 8 (8-12 ppb); these samples contained upper quartile to 90 th percentile $\mathrm{Cu}(80-110 \mathrm{ppm}$ ), and detectable $\mathrm{S}$ (greater than 0.05 to 0.27 weight percent). Two soils from site 4 (13hy090 and 13hy093) collected in the Estelle pluton adjacent to the Timber Creek fault (Wilson and others, 2009; Wilson and others, 2012) (fig. 1) contained detectable $\mathrm{Au}(8$ and $18 \mathrm{ppb}$ ) and $\mathrm{S}$ (0.07-0.08 weight percent). These soils (13hy090 and 13hy093) also contained the highest $\mathrm{Bi}$ concentrations measured in our sampling (4.3 and $4.9 \mathrm{ppm}$ ) as well as 90th percentile As (310 to $410 \mathrm{ppm}$ ) and $\mathrm{Sb}$ (2.2 and $3.3 \mathrm{ppm}$ ). The $18 \mathrm{ppb}$ Au sample contained the higher concentrations of these elements as well as $281 \mathrm{ppm}$ (90th percentile) $\mathrm{Cu}$. The $\mathrm{Au}-\mathrm{As}-\mathrm{Bi} \pm \mathrm{Cu}$ geochemical

Table 2. Gold concentration, spectral characterization, and X-ray diffraction results for samples analyzed from Island Mountain and site 8 in the western Alaska Range.

$[*$, rock sample; Seq, Sequence - additional measurements on same sample shifting Analytical Spectral Device (ASD) spectrometer probe location; Dup, Duplicate - lab duplicate for geochmistry and XRD analyses only; Au_ppm, gold in parts per million; ----, not analyzed; MICA, Material Identification and Characterization Algorithm; $\mathrm{XRD}, \mathrm{X}$-ray diffraction; <, not detected; tr, trace]

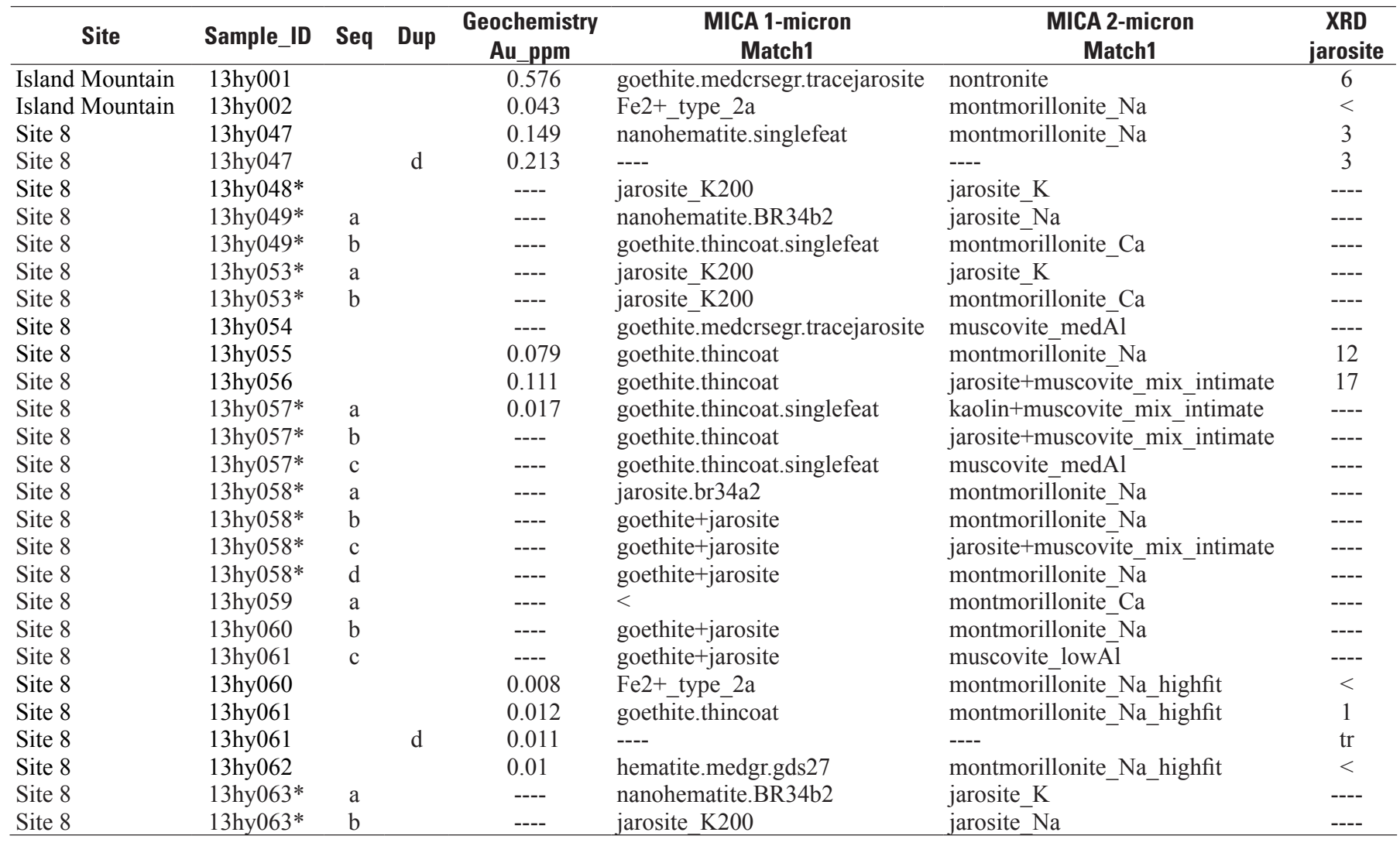


signature is similar to that recognized in sheeted vein prospects known elsewhere in the Estelle pluton (for example, Graham and others, 2013). High concentrations of other metals occurred in some other samples as well, as can be seen in the database.

The five rock samples contained $\mathrm{Au}$ ranging from less than 5 to $17 \mathrm{ppb}$. The two samples containing Au at $17 \mathrm{ppb}$ were from site 8 (13hy057) and from the Ptarmigan site (13hy107). The Ptarmigan sample contained $450 \mathrm{ppm}$ As and $29.8 \mathrm{ppm}$ Sb. The site 8 sample contained detectable (1.1 weight percent) $\mathrm{S}$. Concentrations of other metals in these two samples were not significantly elevated relative to other rock samples analyzed.

\section{Spectral Analysis}

The results of the 1-micron and 2-micron MICA mineral identifications for all of the sample, point and linear traverse spectra are summarized as follows. For the 1-micron wavelength region, goethite was the most common mineral identified throughout most of the measurements. Only sporadic nanohematite and $\mathrm{Fe}^{2+}$ type_2a (that is, a broad absorption feature similar to that exhibited by the amphibole mineral cummingtonite; Kokaly and others, 2013) classifications were output during 1-micron MICA spectral analyses. For the 2-micron wavelength region, montmorillonite and kaolinite were the most commonly identified minerals. Notably, jarosite was associated with some 1-micron spectral features measured at site 16 (13hy005, 13hy007, and 13hy008), Island Mountain (13hy001), site 6 (13hy115), Kohlsaat east (13hy098), Jimmy Lake (13hy123), and with 1 and 2-micron spectral features in 9 samples from site 8 (13hy048, 13hy049, 13hy053, 13hy054, 13hy056, 13hy057, 13hy058, 13hy059, 13hy063). For Island Mountain and site 8 where jarosite was identified by MICA, the geochemistry analysis results showed samples contained elevated $\mathrm{Au}$ (table 2).

\section{X-ray Diffraction}

The X-ray diffraction analyses demonstrate that all soil samples contain at least 51 percent total quartz, plagioclase, and potassium feldspar (median of 89 percent by surface area of sample analyzed). Other igneous rock-forming minerals detected include amphiboles and micas (biotite and muscovite [grouped with illite]). Alteration/weathering products include chlorite and various clays. Chlorite was identified mostly on the western side of our study area. Clays compose up to 27 percent by surface area of sample analyzed, include smectite and kaolinite groups, and are likely weathering products of the mostly granitic rocks observed at sample sites.

Jarosite was present or quantified by XRD in samples from two areas, Island Mountain (13hy001) and site 8 (13hy047, 13hy055, 13hy056, 13hy061, and 13hy062), where geochemical analyses established $\mathrm{Au}$ concentrations exceeded $100 \mathrm{ppb}$. Hematite was only identified in site 8 (13hy047, 13hy055, 13hy056, 13hy060, 13hy061, and 13hy062), where strong red, orange, and yellow staining produces a strong color anomaly (fig. 2).

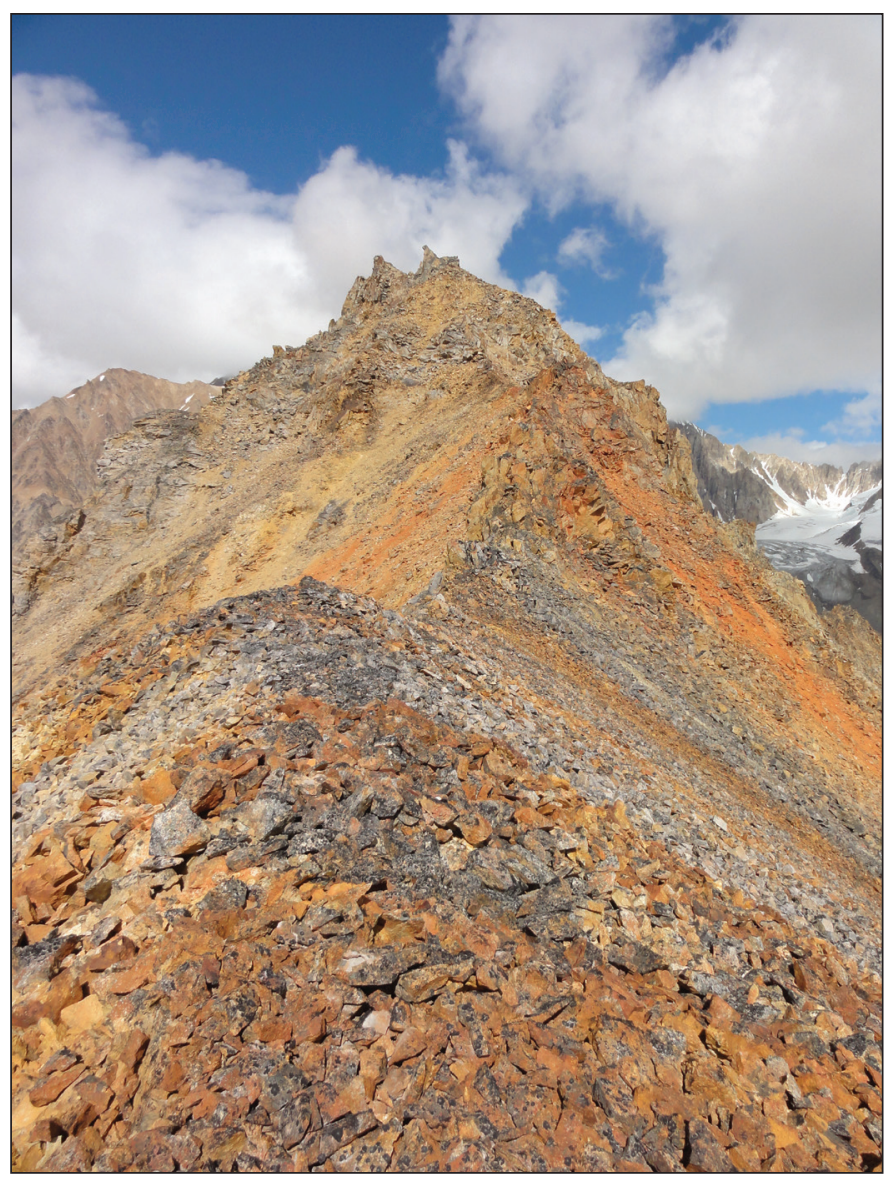

Figure 2. Photograph showing strong color anomaly from site 8 approximately 30 kilometers southeast of Mount Estelle in the western Alaska Range, Alaska (Photograph by: Michaela Johnson, July 16, 2013).

\section{Results Summary}

Jarosite is discussed in this Data Series because of its presence and combination with clays in mineral assemblages in advanced argillic alteration that can be related to goldbearing epithermal systems and their amenability to detection in spectral measurements (Thompson and others, 2009) (table 1). Table 2 shows Au analysis of reconnaissance samples, MICA spectral, and XRD results for select constituents. Results from XRD and MICA analyses confirm the presence of jarosite in most samples where Au is greater than $10 \mathrm{ppb}$. In this sampling area, detection of jarosite could be important for identifying areas that are prospective for $\mathrm{Au}$ deposits.

\section{Geodatabase Description}

\section{Overview}

An Environmental Systems Research Institute (Esri) geodatabase (Zeiler, 2010; Esri, 2014) was created to facilitate the sharing of sample geographic locations, site photos, geochemical, and spectral (MICA PRISM) and XRD analyses results. 


\section{Geodatabase Structure and Contents}

The feature classes in the geodatabase are of two categories: (1) an in situ category with both spectral traverse measurements (line) and spectral sample measurements (point) features for data collected at the field sites and (2) a grab sample (point) category for data collected on samples removed from the field. The attribute tables for each point and line feature class-representing sampling locations have a unique identifier that relates the locations to the analyses results that are included as tables within the geodatabase and structured similarly in a separate directory (RESULTS data_tables) within the shapefile version (fig. 3): RESULTS_Geochemical_analysis_July2013, RESULTS MICA_1micron_July2013, RESULTS_MICA_2micron_ July2013, and RESULTS_XRD_analysis_July2013.

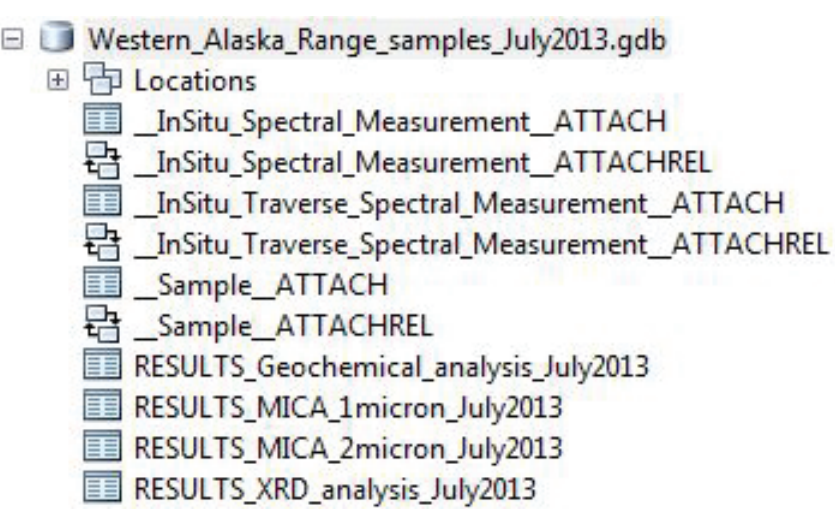

Figure 3. Location of analyses results tables within the geodatabase structure.
The spectral measurements for in situ features (line and point) are related to the MICA results by the unique identifier field, SPECPRno,containing the SPECPR record number (fig 4). The rock and soil samples are related by the field, Sample_ID, that correspond to the corresponding field within the geochemical, XRD, and MICA results (fig. 4). Samples may contain more than one result per sample (for example duplicate [d] for geochemical and XRD and sequence letters $[\mathrm{a}-\mathrm{h}]$ for multiple spectral measurements per sample). The sequence letters correspond to multiple spectral measurements shifting the location of the spectral probe over the sample. The results were not composited but provided by sample as a sequence of measurements with results.

In the geodatabase and shapefile version (layer file), relationships have been provided as relates between the features and the associated results tables. The in situ features (line and point) have relates set up to the MICA results tables, as these were only in situ measurements and there were no samples collected. The samples have a relate set up for each result table: geochemical, XRD, 1-micron MICA, and 2-micron MICA. These related results tables can be accessed directly using the identity tool (fig. 5) or within attribute tables through the button at the top of the table: "Related Tables" (fig. 6). The user can identify any feature class and access the associated results. If there are multiple results per feature, all of the associated results are listed. In the geodatabase version, if a group of features (for example, all features for site 8) are selected and shown in the attribute table for the feature class, "Sample," the related table (for example 1-micron MICA) can be opened only showing the results for those selected sites using the button "Related Tables."

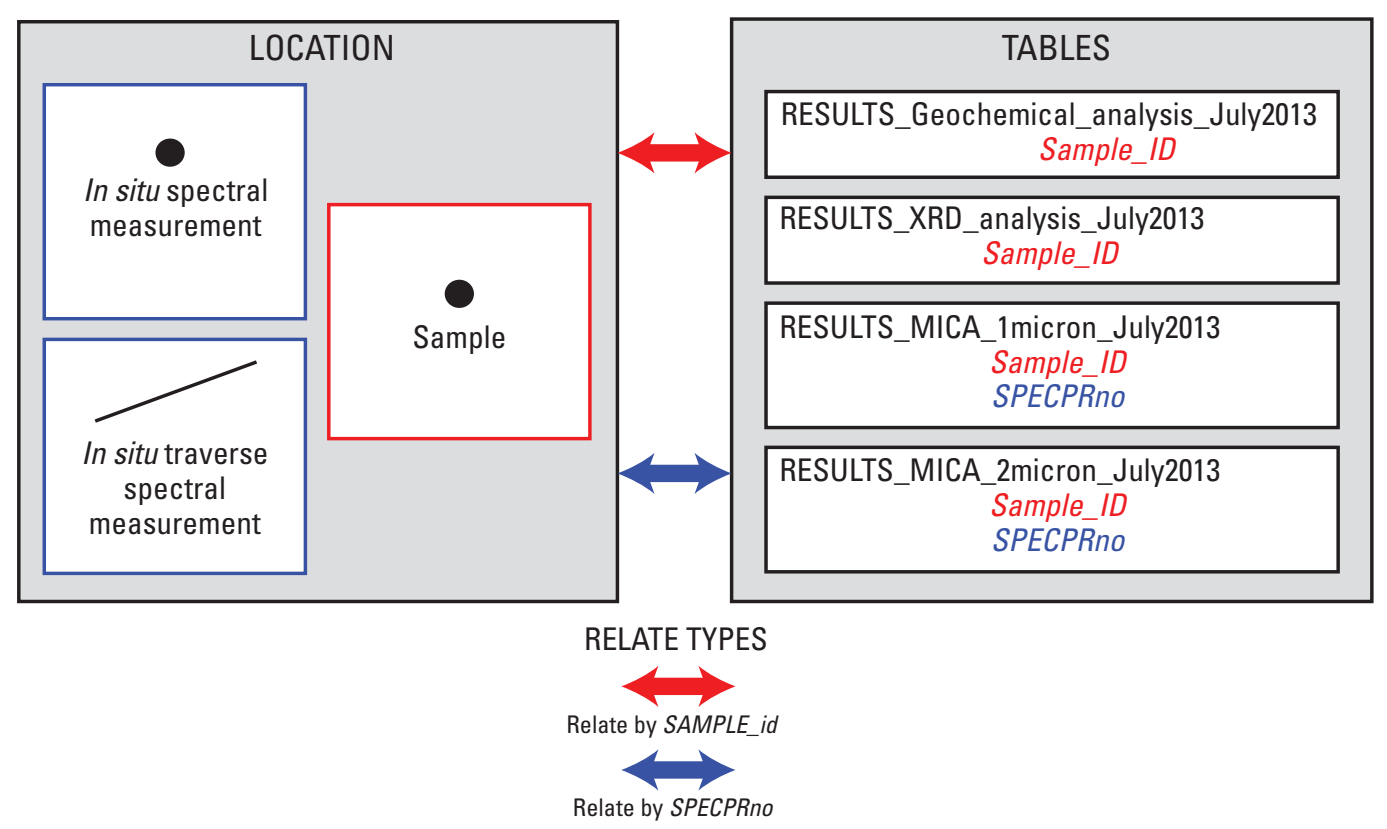

Figure 4. Illustration of geodatabase relationships between feature classes within the feature dataset, location, and the analyses results for spectral measurements and grab samples collected July 2013 in the western Alaska Range. 


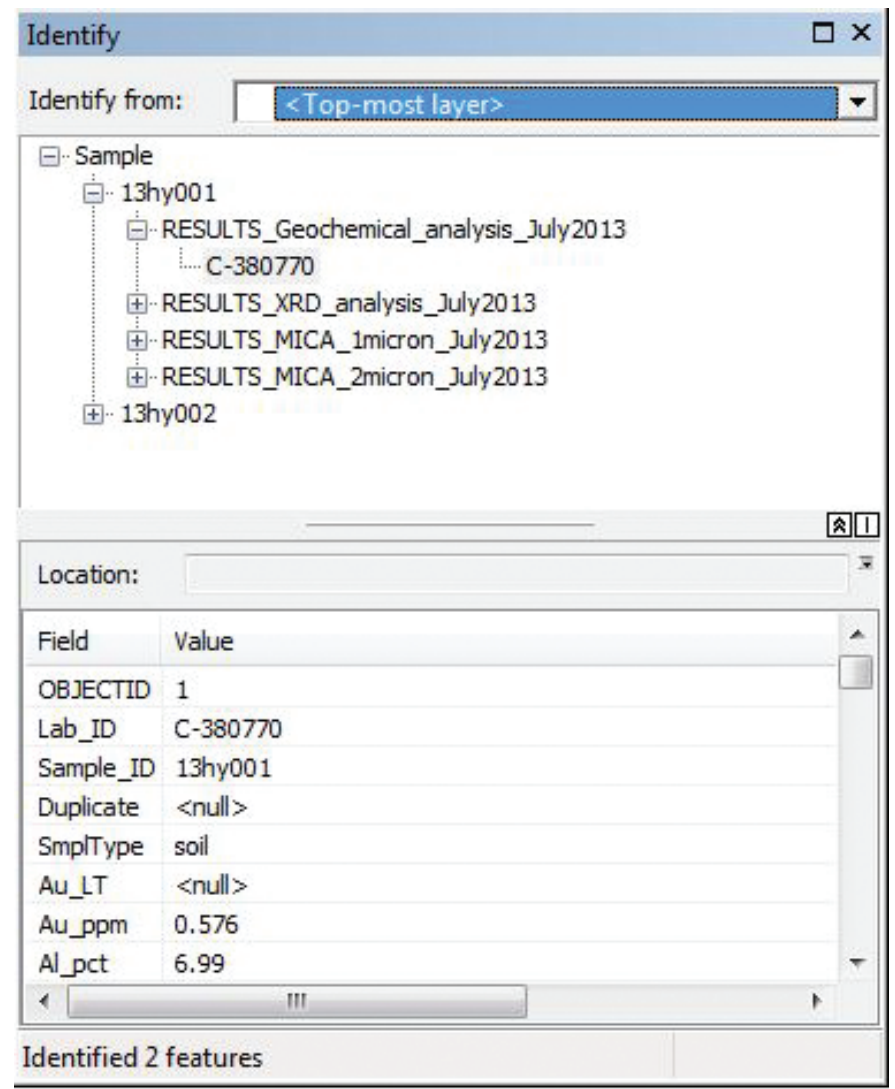

Figure 5. Graphic showing the capability of accessing related table information from within the identity tool.
Sample photos can be accessed and displayed within the ArcGIS environment. The photos were added as attachments to the geodatabase feature classes in the feature dataset, Location, and are accessed as HTML popups that display the photo and table contents (fig. 7). The HTML popup button is two to the right of the identity button with the hyperlink button (lightning bolt) in the middle and to the left of the measurement button (ruler) (fig. 8).

In the shapefile version the photos can be linked by configuring the HTML Popup settings under Layer Properties. The following HTML Popup settings should be modified (fig. 9):

- Check ON 'Show content for this layer using the HTML Popup tool'

- Select button 'As a URL'

- Change the text in the space next to "Prefix:" from $<$ replace with directory location $>$ to the local computer location. If the directory $\backslash$ photo is located here: c: Itemp $\backslash$ Western_Alaska_Range_samples_ July2013_shp\photo,

- Set 'Prefix:' to c: \temp $\backslash$ Western_Alaska_Range_ samples_July2013_shp

- This completes the full directory location used in combination with the text in the field, PhotoLink

- Field to be selected in dropdown box: PhotoLink

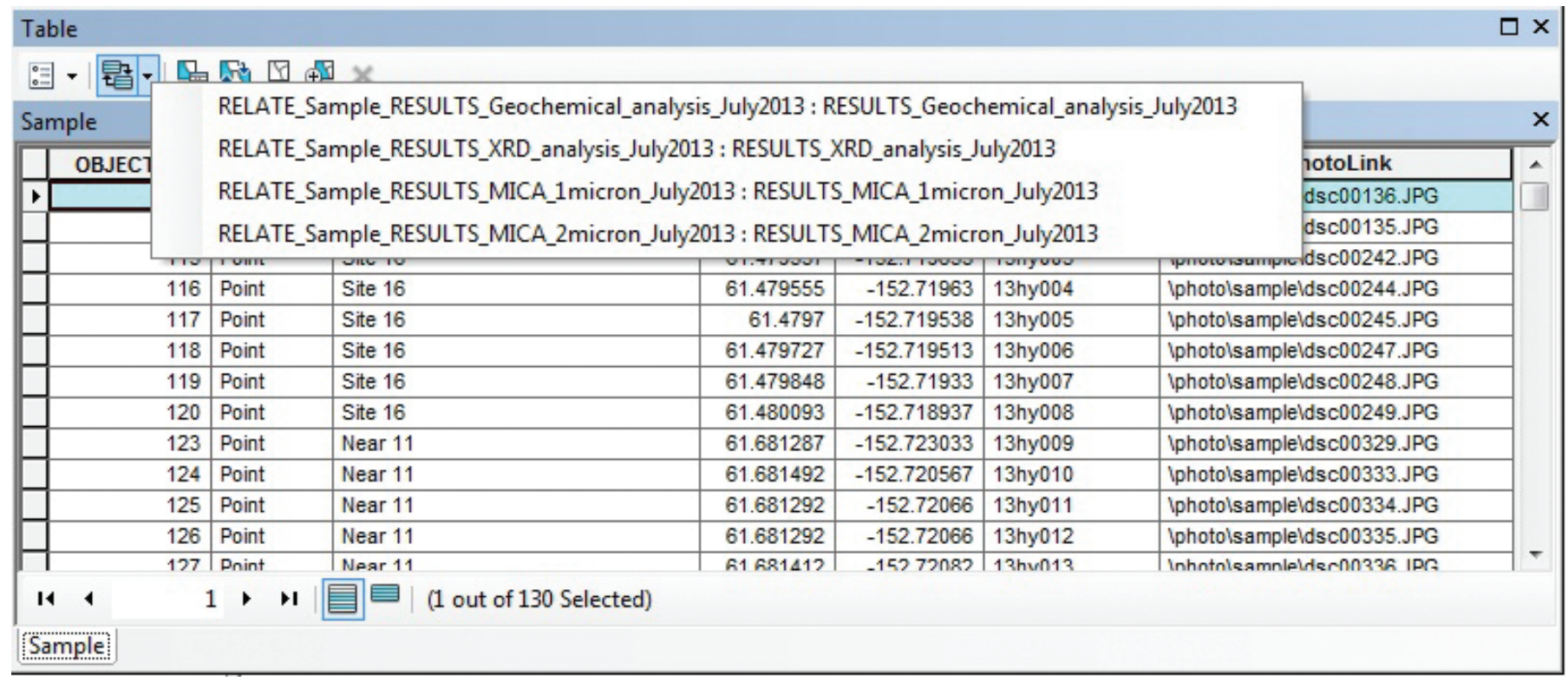

Figure 6. Graphic showing the capability of accessing related tables from within an attribute tables using the button, "Related Tables." 


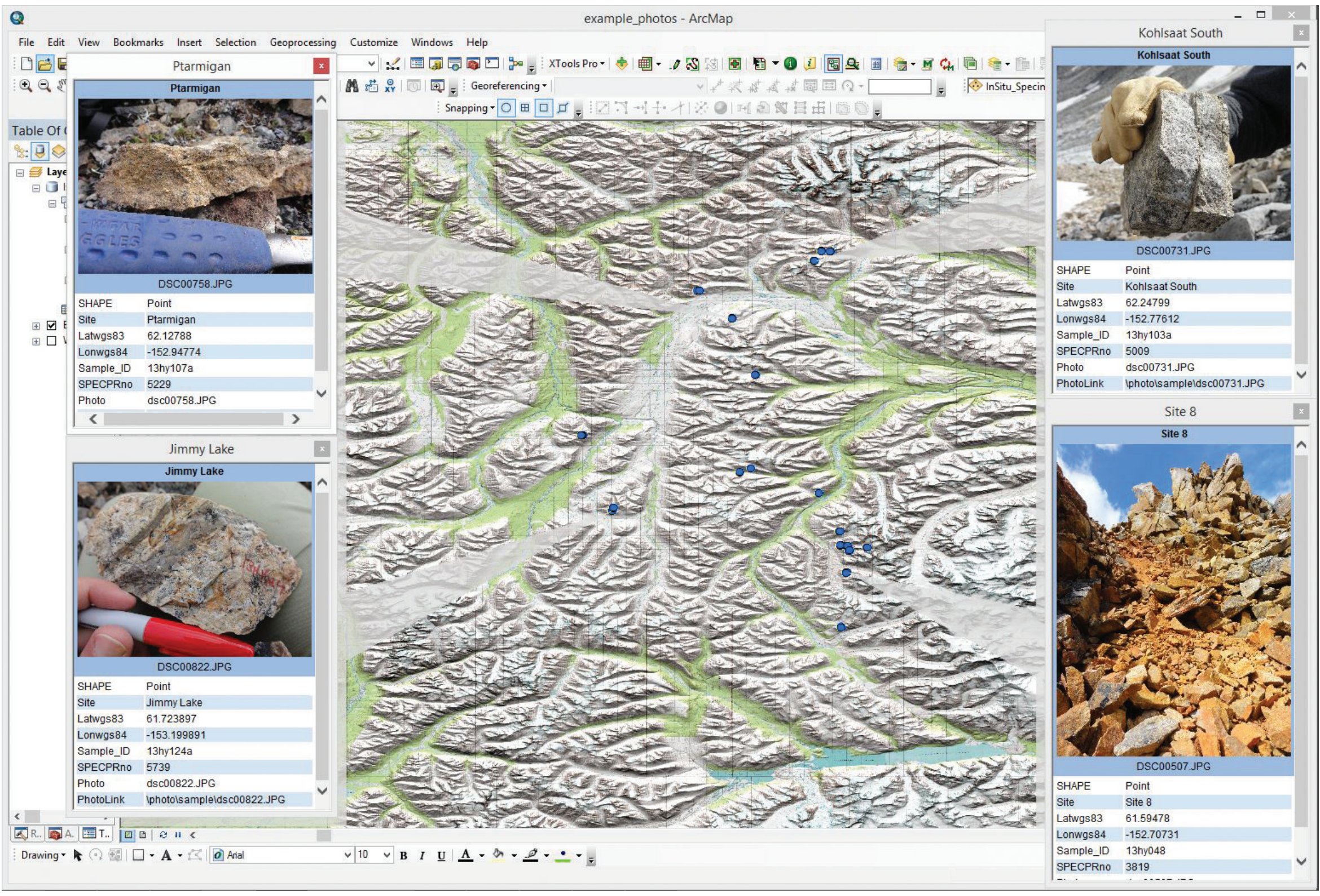

Figure 7. Example of geodatabase display showing the site location and information with the associated photos within the ArcGIS environment. 


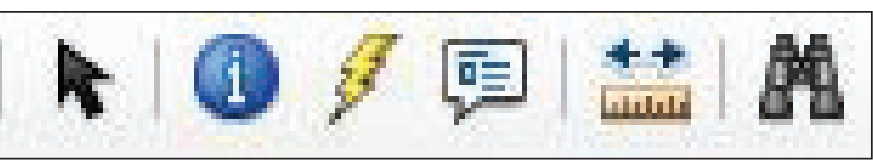

Figure 8. Graphic showing location of the HTML popup button; right of hyperlink button (lightning bolt) and left of measurement button (ruler).

\section{Availability of Data}

The point and line feature classes in the geodatabase have been exported to a nonproprietary format: shapefile (Esri, 1998), in order to facilitate sharing. The data are provided with this report in the file geodatabase version as well as shapefiles with comma-delimited tables of the analyses results (geochemical, MICA, and XRD) and Federal Geographic Data Committee compliant metadata.

\section{Discussion}

Field and laboratory based analysis of spectral, mineralogical, and geochemical characteristics of the soils from sites visited in 2013 indicate that many of the samples contain iron oxides and various clays that could be formed by weathering of granitic rocks that are widespread in the area. Two areas, Island Mountain and site 8, contain both the highest Au concentrations and the highest elevated trace metal concentrations in the study. Jarosite was identified in multiple samples by XRD analysis, and only in samples from these two sites. While spectral analysis did not detect jarosite for all of the same samples, it was identified at site 16, site 6, Kohlsaat east, Jimmy Lake, Island Mountain, and multiple samples from site 8. In this sampling area, detection of jarosite could be important for identifying areas that are prospective for gold deposits.

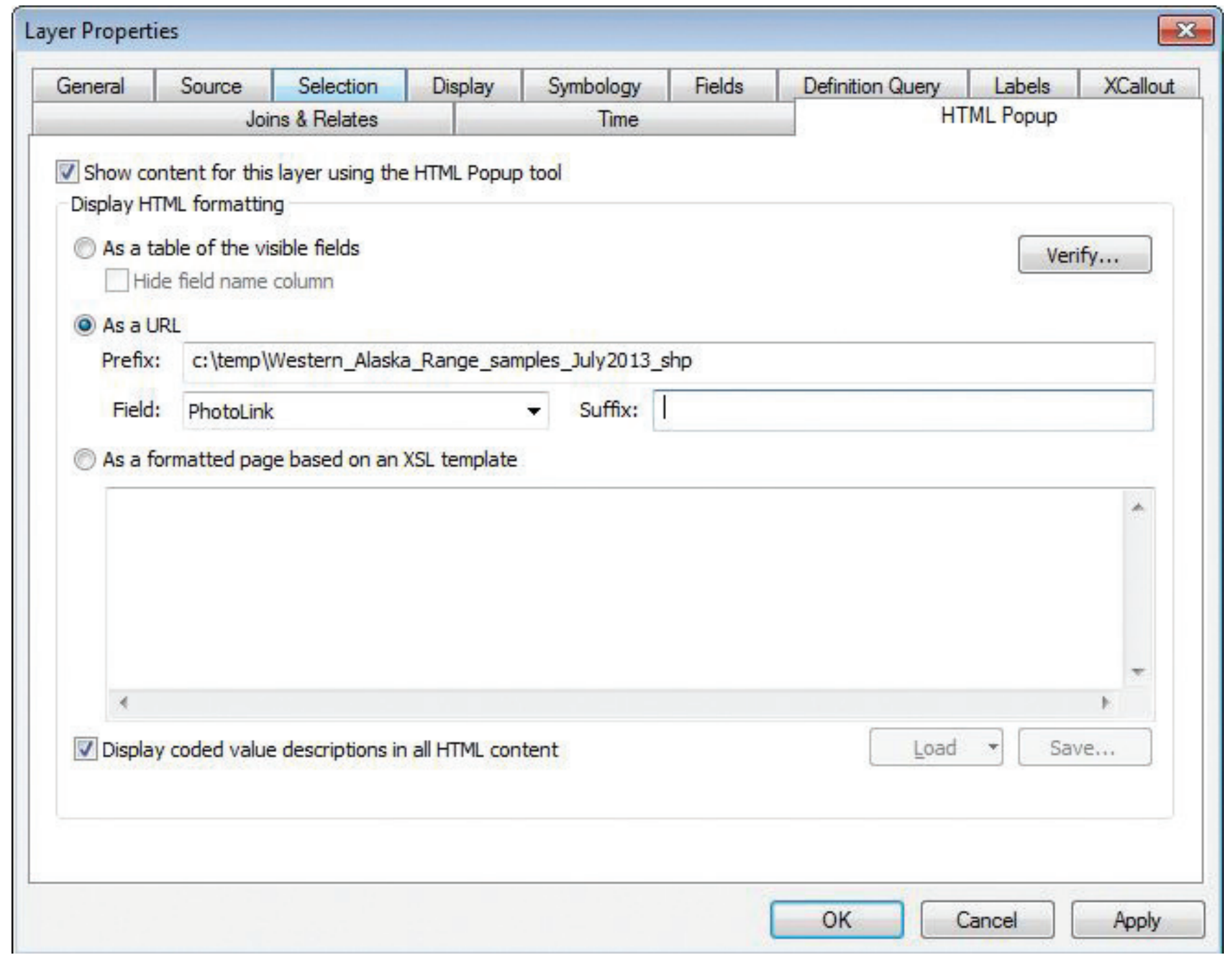

Figure 9. Configuration of HTML Popup tool for shapefile version of the dataset. 


\section{References Cited}

Clark, R.N., 1993, SPECtrum Processing Routines user's manual version 3 (program SPECPR): U.S. Geological Survey Open-File Report 93-595, 210 p., at http://speclab.cr.usgs.gov.

Clark, R.N., Swayze, G.A., Livo, K.E., Kokaly, R.F., Sutley, S.J., Dalton, J.B., McDougal, R.R., and Gent, C.A., 2003, Imaging spectroscopy_-Earth and planetary remote sensing with the USGS Tetracorder and expert systems: Journal of Geophysical Research, v. 108, no. E12, p. 5-1-5-44, doi:10.1029/2002JE001847.

Clark, R.N., Swayze, G.A., Wise, R.A., Livo, K.E., Hoefen, T.M., Kokaly, R.F., and Sutley, S.J., 2007, USGS digital spectral library splib06a: U.S. Geological Survey Digital Data Series 231, accessed August 28, 2014, at http://speclab.cr.usgs.gov/spectral.lib06/.

Cocks, T., Jenssen, R., Stewart, A., Wilson, I., and Shields, T., 1998, The HyMap airborne hyperspectral sensor-The system, calibration and performance, in Schaepman, M., Schlapfer, D., and Itten, K.I., eds.: EARSeL Workshop on Imaging Spectroscopy, 1, 6-8 October 1998, Zurich, Switzerland, Proceedings: Paris, EARSeL, p. 37-43.

Esri, 1998, ESRI shapefile technical description: Redlands, Calif., Environmental Systems Research Institute, accessed December 31, 2014, at http://www.esri.com/library/ whitepapers/pdfs/shapefile.pdf/.

Esri, 2014, ArcGIS help 10.1-What is a geodatabase?: Redlands, Calif., Environmental Systems Research Institute, accessed May 26, 2015 at http://resources.arcgis.com/ en/help/main/10.2/\#/What_is_a_geodatabase/ 003n00000001000000/.

Fachinformationszentrum Karlsruhe (FIZ) and the National Institute of Standards and Technology (NIST), 2014, FIZ/ NIST inorganic crystal structure database (ICSD): Gaithersburg, Md., National Institute of Standards and Technology, NIST Standard Reference Database 84, accessed September 24, 2014, at http://www.nist.gov/srd/nist84.cfm/.

Graham, G.E., Goldfarb, R.J., Gibler, M.L., and Roberts, Mike, 2013, Paper 5-Tectonic evolution and Cretaceous gold metallogenesis of southwestern Alaska, in Colpron, Maurice, Bissig, Thomas, Rusk, B.G., and Thompson, J.F.H., eds., Tectonics, mettalogeny, and discovery-The North American cordillera and similar accretionary settings: Society of Economic Geologists, Special Publication No. 17, p. 169-200.
Hubbard, B.E., Rowan, L.C., Dusel-Bacon, Cynthia, and Eppinger, R.G., 2007, Geologic mapping and mineral resource assessment of the Healy and Talkeetna Mountains Quadrangles, Alaska using minimal cloud- and snowcover ASTER sata: U.S. Geological Survey Open-File Report 2007-1046, http://pubs.usgs.gov/of/2007/1046/.

International Centre for Diffraction Data, 2010, Powder diffraction file, PDF-4+ 2009: Newtown Square, Penn., International Centre for Diffraction Data.

King, T.V.V., Kokaly, R.F., Hoefen, T.M., Dudek, K.B., and Livo, K.E., 2011, Surface materials map of Afghanistan-Ironbearing minerals and other materials. U.S. Geological Survey Scientific Investigations Map 3152-B, scale 1:1,100,000, http://pubs.usgs.gov/sim/3152/B/.

Kokaly, R.F., 2011, PRISM—Processing routines in IDL for spectroscopic measurements (installation manual and user's guide, version 1.0): U.S. Geological Survey OpenFile Report 2011-1155, 432 p., http://pubs.usgs.gov/ of/2011/1155/.

Kokaly, R.F., King, T.V.V., and Hoefen, T.M., 2013, Surface mineral maps of Afghanistan derived from HyMapTM imaging spectrometer data, version 2: U.S. Geological Survey Data Series 787, http://pubs.usgs.gov/ds/787/.

Kokaly, R.F., King, T.V.V., Hoefen, T.M., Dudek, K. and Livo, K.E., 2011, Surface materials map of AfghanistanCarbonates, phyllosilicates, sulfates, altered minerals, and other materials: U.S. Geological Survey Scientific Investigations Map 3152-A, scale 1:1,100,000, http://pubs.usgs.gov/sim/3152/A/.

Materials Data Inc., 2009, Jade XRD Pattern Processing, Identification, and Quantification Software., V9.5, Livermore, Calif., accessed September 24, 2014, at http://www.materialsdata.com/.

Moore, D.M., and Reynolds, R.C., 1997, X-ray diffraction and the identification and analysis of clay minerals $(2 \mathrm{~d} \mathrm{ed}$.): New York, Oxford University Press, 378 p.

National Aeronautics and Space Administration (NASA) Jet Propulsion Laboratory (JPL), 2014, Advanced spaceborne thermal emission and reflection radiometer (ASTER) Mission, NASA-JPL, accessed June 23, 2014, at http://asterweb.jpl.nasa.gov/mission.asp.

PANalytical, 2014, X-ray diffractometers: PANalytical, accessed May 26, 2015, at http://www.panalytical.com/ Xray-diffractometers.htm.

Poppe, L.J., Paskevich, V.F., Hathaway, J.C., and Blackwood, D.S., 2001, A laboratory manual for X-ray powder diffraction: U.S. Geological Survey Open-File Report 2001-41, CD-ROM, accessed April 21, 2015, at http://pubs.usgs.gov/ of/2001/of01-041/. 
Reed, B.L., and Elliott, R.L., 1970, Reconnaissance geologic map, analyses of bedrock and stream-sediment samples, and an aeromagnetic map of parts of the southern Alaska Range: U.S. Geological Survey Open-File Report 70-271, 145 p., 4 sheets, scale 1:125,000.

SGS Minerals Services, 2013, Fire Assay Gold-Analytical Services: SGS Mineral Services-T3 SGS 218, accessed May 26, 2015, at http://www.sgs.com/ /media/Global/ Documents/Flyers\%20and\%20Leaflets/SGS-MINWA292-Fire-Assay-Gold-EN-11.pdf/.

Thompson, A.J.B, Hauff, P.L., and Robitaille, A.J., 2009, Alteration mapping in exploration-Application of ShortWave Infrared (SWIR) spectroscopy: Society of Economic Geologists (SEG) Reviews in Economic Geology, v. 16, p. $12-23$.

U.S. Geological Survey, 2012, Alaska resource data file (ARDF): U.S. Geological Survey,accessed September 25, 2014, at http://ardf.wr.usgs.gov/. [Digital data]

U.S. Geological Survey, 2014, Landsat 8: U.S. Geological Survey, accessed December 16, 2014, at http://landsat.usgs.gov/ landsat8.php/.
Wilson, F.H., Hults, C.P., Schmoll, H.R., Haeussler, P.J., Schmidt, J.M., Yehle, L.A., and Labay, K.A., comps., digital files prepared by Wilson, F.H., Hults, C.P., Labay, K.A., and Shew, Nora, 2009, Preliminary geologic map of the Cook Inlet region, Alaska-Including parts of the Talkeetna, Talkeetna Mountains, Tyonek, Anchorage, Lake Clark, Kenai, Seward, Iliamna, Seldovia, Mount Katmai, and Afognak 1:250,000-scale quadrangles: U.S. Geological Survey Open-File Report 2009-1108, scale 1:250,000, accessed January 9, 2015, at http:/pubs.usgs.gov/of/2009/1108/.

Wilson, F.H., Hults, C.P., Schmoll, H.R., Haeussler, P.J., Schmidt, J.M., Yehle, L.A., and Labay, K.A., comps., 2012, Geologic map of the Cook Inlet region, Alaska-Including parts of the Talkeetna, Talkeetna Mountains, Tyonek, Anchorage, Lake Clark, Kenai, Seward, Iliamna, Seldovia, Mount Katmai, and Afognak 1:250,000-scale quadrangles: U.S. Geological Survey Scientific Investigations Map 3153, 76 p., 2 sheets, scale 1:250,000, http://pubs.usgs.gov/ $\operatorname{sim} / 3153 /$.

Zeiler, Michael, 2010, Modeling our world (2d ed.)—The ESRI guide to geodatabase concepts: Redlands, Calif., ESRI Press, 308 p.
Publishing support provided by:

Denver Publishing Service Center, Denver, Colorado

For more information concerning this publication, contact:

Center Director, USGS Crustal Geophysics and Geochemistry Science Center Box 25046, Mail Stop 964

Denver, CO 80225

(303) 236-1312

Or visit the Crustal Geophysics and Geochemistry Science Center Web site at: http://crustal.usgs.gov/

This publication is available online at: http://dx.doi.org/10.3133/ds943 
